\title{
CREATIVITY AMONG BUSINESS AND TOURISM MANAGEMENT UNIVERSITY STUDENTS: DETERMINING SOCIODEMOGRAPHIC FACTORS
}

\author{
Mercedes MAREQUE ${ }^{1, *}$, Elena DE PRADA ${ }^{2}$, Margarita PINO-JUSTE ${ }^{3}$ \\ ${ }^{1}$ University of Vigo, Faculty of Business Sciences and Tourism, Department of Financial Economics and \\ Accountancy, Campus Universitario, $s / n-32004$, Ourense, Spain \\ ${ }^{2}$ University of Vigo, Faculty of Business Sciences and Tourism, Department of English, French and German \\ Philology, Campus Universitario, $s / n-32004$, Ourense, Spain \\ ${ }^{3}$ University of Vigo, Faculty of Education Sciences and Sports, Department of Didactics, School \\ Organization and Research Methods, Campus A Xunqueira, s/n-36005, Pontevedra, Spain
}

Received 4 December 2018; accepted 5 July 2019

\begin{abstract}
There is a clear link between creativity levels, entrepreneurship and employability that implies the need for higher education students to acquire creative skills and abilities. For this reason, this study aims to analyse creativity levels among university students and verify whether certain sociodemographic factors have an impact on creativity. Two approaches were applied to measure creativity; on one hand, divergent thinking measured through three tasks, originality, fluency and flexibility, and creative potential (ideation - Runco Ideational Behavior Scale) on the other. A survey was administered to 303 Business and Tourism Management degree students during the academic year 2016-2017. The results reveal that our students' creative potential (Runco Ideational Behavior Scale) is relatively high, while the divergent thinking measurements (originality, fluency and flexibility) obtained lower scores. There are gender-based differences in the three divergent thinking constructs, with men gaining higher scores; likewise, differences also appeared in the constructs of fluency and originality depending on the degree being studied, with Business degree students displaying a higher average score. In addition, students living with their families scored higher on flexibility than those that did not. Moreover, students' creative potential (Runco Ideational Behavior Scale) is greater among those who both study and work. These results emphasize the need to encourage the development of creativity among Spanish university students.
\end{abstract}

Keywords: creativity, creative potential, divergent thinking, sociodemographic factors, Business Administration and Management students, Tourism Management students.

\section{Introduction}

Nowadays, there is an unquestionably important link between creativity and success in the business world, both in terms of entrepreneurship (McMullan \& Kenworthy, 2015) and

*Corresponding author. E-mail: chedesmareque@uvigo.es 
employability for all kinds of firms (Epstein, Kaminaka, Phan, \& Uda, 2013), with an assessment that goes beyond executive posts to affect all employees (Zhou, 2007). This growing requirement for future candidates to the job market to have a creative profile has resulted in the need for the organisms in charge of educating students to adapt to the demands of the business sphere.

As the main higher education organisation that supplies companies and prepares future entrepreneurs, the objective of universities should be to prepare students in the best way possible. Universities should equip students with the tools to be able to think and create, given that they are the ideal space in which to promote teaching-learning through creativity, while not forgetting the important contribution of the teaching staff to this process (Burkšaitienè, 2018); university programmes should therefore include tasks that develop creativity in their students.

The European Higher Education Area (EHEA) is aware of this need, specifically recommending that creativity be included in the criteria with which all the competences are organised; in this way the EHEA recognises creativity to be a highly important element in students' overall competence training. Furthermore, in the Recommendation of the European Parliament and of the Council of 18 December 2006 on Key Competences for Lifelong Learning (2006), the European Union highlights creativity, as well as other closely linked content such as critical thinking and problem solving, as essential elements that should be applied and which are of particular importance to entrepreneurship (Eggers, Lovelace, \& Kraft, 2017).

Nevertheless, the role of creativity as a competence is not predominant in many universities. Thus, we have ascertained that creativity does not figure as a cross-curricular skill to be developed in many syllabuses of Business Administration and Management (BAM) and Tourism Management (TM) degrees in Spanish public universities, in spite of the evidence underscoring its relevance to the correct performance of many tasks within the business sphere. In fact, candidates' creative abilities/skills are valued more and more in company recruitment processes (Kerr \& Lloyd, 2008a; Epstein et al., 2013).

Other articles have also highlighted the importance of including creativity in Business and Management studies. Regina Pefanis Schlee and Katrin R. Harich (2014) in a study carried out in United States highlight the importance of the connection between creativity and innovative thinking and the need to include this topic in the academic curriculum to business students, following the recommendation of the report by the Association to Advance Collegiate Schools of Business (AACSB) regarding the benefit of educational establishments promoting the acquisition of creative problem-solving skills in order to increase innovation and entrepreneurship (2010, p. 133). Michael J. Fekula (2011), Cheryl Kerr and Cathryn Lloyd (2008b) or Jane Schmidt-Wilk (2011) agree that creativity should be included in business studies syllabuses, a need that is reinforced by the fact that the comparative studies carried out revealed that business studies students scored lower in this competence than students of other areas (McIntyre, Hite, \& Kay Rickard, 2003; Wang, Peck, \& Chern, 2010). In the same line, Koustab Ghosh (2014), after an exhaustive critical review on the importance of creativity and innovation in firms, defends the need to include this in the academic curriculum of business schools. 
Therefore, we believe that establishing which are the factors that promote creative decision-making is a necessary step. Leobardo Durón Tafoya and Roberto Oropeza Tena (1999) indicate that those factors which impact student creativity and entrepreneurship are related to both educational and sociodemographic factors (SDFs). Educational factors refer to the quality of teaching, that is, the number of students per teacher, the teaching methodology and materials used, student motivation and the time invested by teachers in class preparation. SDFs are the socioeconomic, biological and family-related factors that may affect students, such as age, gender, family type, marital status, place of origin, occupation, level of studies among family members or family income. This study focuses on the second group of factors, attempting to analyse whether certain SDFs have a positive impact on the creativity of university students. In turn, this should lead us to new ideas and opportunities that contribute to a better adaptation to the work market on the part of the students, who should find themselves better prepared to take on new challenges; likewise, we should be able to devise actions and strategies to improve student creativity and the teaching-learning methodology used by the teaching staff.

This paper is organized in the following sections: after the first introductory section, the second section describes the theoretical background and the hypotheses, the third section presents the methodology used in the study, the fourth section shows the results, the fifth section contains the discussion, with the conclusions and the most relevant implications, to end with the limitations and future research of the study.

\section{Theoretical background and hypotheses}

\subsection{The importance of creativity in university studies and the tools to measure it}

Creativity is one of the most complex processes in human beings, which implies having thinking skills that enable the integration of both less complicated cognitive processes and the so-called higher processes; the latter are involved in the formation of ideas or new thoughts (Esquivias Serrano, 2004). Creativity has always existed, although it was not until around the mid-20th century when this concept began to be studied in depth. One of the first researchers in this area, J. P. Guilford (1962), sustained that creative individuals have certain divergent thinking (DT) skills, such as ideational fluency, flexibility or original thinking. Along the same lines, Michael Wallach and Nathan Kogan (1965) define creativity as the generation of abundant (fluency) and unique (originality) ideas. Other authors such as Teresa Amabile (1983), Steven J. Kachelmeier, Bernhard E. Reichert and Michael G. Williamson (2008) or Carl R. Rogers (1959) define creativity as the production of unique and useful products, services, processes, or procedures.

Research into creativity has sprung from various areas, including education, especially in the primary and secondary stages, although university education is the least studied area in terms of creativity (Cheung, Rudowicz, Yue, \& Kwan, 2003; Fitó-Bertran, HernándezLara, \& Serradell-López, 2014). These authors defend a university education system that fosters creative thinking and the incorporation of elements and tools in order to develop 
high performance abilities, as well as the implementation of innovative and entrepreneurial activities.

Creativity in university education is a highly relevant issue, given that students in this context have to deal with varying work environments, teaching strategies and models. University is the ideal space to promote teaching-learning among students, thus contributing to the development of their creative potential (CP); it should be an environment wherein individuals are trained to be capable of thinking and creating for themselves. It is therefore essential that university students develop their creativity in order to be able to look for and propose the most creative solutions for the variety of problems they will come across, since creativity is essential to problem-solving (Couger, 1994, 1996; Wynder, 2008), is a precursor to innovation (Shalley, Zhou, \& Oldham, 2004) as well as a core competence for entrepreneurship (Ahmetoglu, Harding, Akhtar, \& Chamorro-Premuzic, 2015; Biraglia \& Kadile, 2017; Zampetakis, Gotsi, Andriopoulos, \& Moustakis, 2011).

However, bearing in mind that creativity is a basic cross-curricular competence to be developed by university students, several authors have pointed to the scarce development of this skill in university studies (Cheung et al., 2003; Rinaudo \& Donolo, 1999; Soler, 2003). Specifically, and for the studies analysed here, namely Business Management (BM), recent research has highlighted the importance of the inclusion of creativity development in university curricula (Fekula, 2011; Kerr \& Lloyd, 2008a; Schmidt-Wilk, 2011), given that it would seem that the students of these courses score lower in creativity than students of other degrees (McIntyre et al., 2003; Wang et al., 2010). In this sense, the AACSB highlighted the need for creativity to be given a leading role in current academic curricula; business training centres should promote the acquisition of skills by means of solving creative problems in order to increase innovation. Likewise, other authors such as Ghosh (2014, pp. 172-176) reiterate the need to introduce creativity into academic university curricula so that "creativity development of students becomes a priority in business schools", and puts forward the courses of action to this aim, with of course the necessary collaboration of all those parties involved: enterpriseindustry-faculty-secondary school-student-society. Kerr and Lloyd (2008b) propose specific courses of action based on the arts, the creative process and work groups to develop creativity in future managers and directors.

Creativity is seen as a starting point that brings innovation to organisations, and creative skills enable university students to discover new ideas and opportunities that contribute to innovation. The creative abilities acquired by students positively influence their self-perception of creativity which they will transmit to their work groups, thus giving rise to a positive impact on the perception of the group's support of innovation and their innovative results (Gundry, Ofstein, \& Kickul, 2014).

Thus, the current job market is demanding a more creative profile from prospective applicants, given the important link between creativity and success in the business sphere, related both to entrepreneurial potential (McMullan \& Kenworthy, 2015) and employability (Epstein et al., 2013).

Having reached this point, bearing in mind the aforementioned need to include and promote creativity in university studies and the importance that this competence may have in the future when students embark on their professional careers, we consider it equally 
necessary to establish how students' creativity can be measured. In this sense, one of the greatest difficulties is how to assess creativity in general, and university students' creativity in particular; most of the existing studies evaluating creativity among university students use instruments designed for children and adolescents. These measures may not be the most adequate for use among the university student population, given that this collective may have higher levels of self-fulfilment (Abra \& Valentine-French, 1991; Runco et al., 1991).

Several researchers have put forward different tools for measuring creativity, with J. P. Guilford (1956) and Ellis Paul Torrance $(1966,1998)$ as the pioneers in this area, the first thanks to the multifactorial model that refers to a series of factors for divergent production that are considered essential in defining creative thinking, the second who devised the Torrance Tests of Creative Thinking, in which "already defined" problems are posed to certain subjects who are asked to offer solutions to said problems. More recently, other authors have put forward alternative measurement tests, such as the Creativity Intelligence Test put forward by Francisco Javier Corbalán Berná et al. (2003); in order to measure creativity, this test uses the ability of the subject to pose questions based on graphic material supplied by the Runco Ideational Behavior Scale (RIBS) test developed by Mark Runco, Jonathan A. Plucker, and Woong Lim (2001), which it is based on the measurement of individuals' CP, that is, their capacity to generate a large quantity of alternative ideas that should also be original and differentiated.

One of the necessary components of creativity is DT, an essential ability for the development of creative and different alternatives in problem solving and one which is commonly applied when evaluating CP. CP is the ability to generate a large quantity of alternative ideas which should additionally be original and different among themselves (Runco, 2006; Zhang, 2010). DT tests use a series of criteria or indicators to measure creativity, while the most frequently used characteristics to this aim are fluency, flexibility and originality, all of which are functions of DT. Fluency is the quantity of ideas a person is capable of generating with respect to a given topic; flexibility is the variety and heterogeneity of the ideas produced when problems are approached from different angles; and originality is the characteristic that identifies the idea, process or the product as something unique or different (Penagos-Corzo \& Aluni, 2000).

While there are different instruments for measuring creativity, as mentioned above, it is in fact the DT test that is one of the most commonly used (Runco \& Acar, 2012). Nevertheless, given that some authors consider the use of only one test to be insufficient when measuring a construct as complex as creativity, we have followed the path of other studies and applied two different measures; on the one hand, the RIBS which measures CP and on the other, a construct of three components that measure DT: originality, fluency and flexibility).

\subsection{Sociodemographic factors influencing creativity}

The previous literature has studied diverse sociodemographic variables that may impact on students' level of creativity (Chaiña Sucasaca, 2016; Cheung et al., 2003; Durón \& Oropeza, 1999). In this paper we shall go on to study some of them, specifically gender, degree and academic year, the student's employment status (whether they are studying and working or 
only studying), whether the family has an entrepreneurial background (if the parents own a business/company), and whether the students are living at home or away from home. These factors were chosen due to their relation with creativity, as demonstrated in diverse studies outlined below.

\subsubsection{Gender}

The existing literature on the relation between creativity and gender is inconclusive (see Baer \& Kaufman, 2008; Kaufman, Baer, Agars, \& Loomis, 2010; Sanz de Acedo Baquedano \& Sanz de Acedo Lizarraga, 2012; Stoltzfus, Nibbelink, Vredenburg, \& Thyrum, 2011). When the literature has managed to detect differences in gender, these have been put down to the effects of environment and culture (Cheung \& Lau, 2010; Matud, Rodríguez, \& Grande, 2007). Nevertheless, it is worth pointing out the fact that those studies in which differences were identified generally showed an advantage for males (Abra \& Valentine-French, 1991; Camacho-Miñano \& Campo, 2017; Chadha, 1985; Phipps, 2012; Wilson, Kickul, \& Marlino, 2007). Considering the aforementioned results, the following hypothesis is posed:

Hypothesis 1. Male students are more creative than female ones.

\subsubsection{Degree and academic year}

Different university degrees may have a varying impact on creativity; the latter may vary depending on the degree studied, as the students display different abilities and thought processes (Cheung et al., 2003). James Hartley and Michael A. Greggs (1997) and Michelle A. Webster and M. B. Walker (1981) observe differences in creativity between arts and science students through the application of DT instruments. Their results suggest that English Studies and arts students show greater creativity than science and business students. On the other hand, the empirical evidence further suggests that an individual's creativity decreases in proportion to an increase in the number of years of formal education (Dacey \& Lennon, 1998; Simonton, 1988). Dean Simonton (1988) notes the existence of a relationship between education and creativity, identifying a peak in creativity during the first years of university. Chau-Kiu Cheung et al. (2003) observe a decrease in creativity over the course of university studies, the most evident being among technology and science students compared to business students.

In line with the evidence above and bearing in mind the fact that creativity is included as a cross-curricular subject to be developed in the programme for the TM degree while not being included in the BAM degree, we put forward the following hypotheses:

Hypothesis 2. TM students are more creative that BAM students.

Hypothesis 3. Students in the first years are more creative than those in the higher years.

\subsubsection{Students' employment status}

Research in the area of students' employment status is scarce and has come to the conclusion that this can have both positive and negative effects on students; its impact will depend on the type of student, their background and their work experience, as well as the attitudes of both the employer and the educational institution (Watts, 2002). 
In most of the studies that revealed negative effects related to combining work and studies, these effects were related to student performance in particular (Broadbridge \& Swanson, 2005; Sorensen \& Winn, 1993). Valerie Holmes (2008) mentions the fact that those students who both work and study have less time to study, are more tired, miss class more and have problems with time management.

In contrast, other studies highlight the positive effects of university students working part-time (Broadbridge \& Swanson, 2005; Lucas \& Lammont, 1998; Sorensen \& Winn, 1993). Susan Curtis and John Williams (2002) note that employment aided students in their acquisition and improvement of certain competences related to interpersonal skills, self-sufficiency, the ability to deal with employers and with the increase in maturity and the ability to organise all kinds of work. Working and studying also offers opportunities to take on greater responsibilities and cooperative interdependence (D’Amico, 1984). Rosemary Lucas and Norma Lammont (1998) state that students who work and study acquire social and communication skills, have a greater ability to handle and resolve delicate and even hostile situations with a greater level of diplomacy and tact, and have a greater ability to work in teams. Catherine Watts and Angela Pickering (2000) indicate the acquisition of transferable skills, an increase in employability and confidence in the work market, and improved organisational and timemanagement skills. Therefore, the following hypothesis is posed:

Hypothesis 4 . Those students who study and work at the same time are more creative.

\subsubsection{Previous experiences of family entrepreneurship}

Several studies refer to students' family circumstances from the point of view of the parents' employment. Leonidas A. Zampetakis (2008) found that those students whose parents had a business displayed a higher level of creative ideas in comparison with those whose parents were not entrepreneurs. Creativity has furthermore been related to students' entrepreneurial potential from the point of view of the kind of work done by the parents. A section of these studies approaches the research from the perspective of self-employed parents, while another examines cases in which parents were majority owners of a business. Regarding the former, the results were mixed; on one hand, some studies corroborate the relationship between students' entrepreneurial intentions and their parents' self-employed status (Bagheri \& Lope Pihie, 2010; Scherer, Adams, Carley, \& Wiebe, 1989; Schmitt-Rodermund, 2004; Tarling, Jones, \& Murphy, 2016), while on the other, such a relationship was not identified (CamachoMiñano \& Campo, 2017; Chen, Gene Greene, \& Crick, 1998; Wilson et al., 2007). With respect to the latter studies, J. Michael Crant (1996), Zampetakis (2008) and Zampetakis and Vassilis Moustakis (2006) establish a link between students' entrepreneurial intentions and the fact that their parents are majority owners of a business. The resulting hypothesis can be posed as follows:

Hypothesis 5. Students who come from an entrepreneurial family are more creative.

\subsubsection{Living at home or away from home}

Some studies highlight the importance of growing up in a family context that fosters the development of creativity, determined by the number of siblings or the age gap between them, the parents' economic position or marital status (married, separated...) (Runco, 
2007). The family offers opportunities, experiences and therefore a variety of options that may play a relevant role in children's creativity (Cheung et al., 2003), although their independence from the family nest during their university life, when most of them are living in student residences or flat-sharing, should lead to an increase in their creative abilities. While we are unaware of whether or not this situation has been studied, we put forward the following hypothesis:

Hypothesis 6. Students living away from home are more creative.

\section{Research methodology}

\subsection{Sampling procedure and participants}

An exploratory descriptive study with a quasi-experimental design has been carried out with an interpretive objective. Quasi-experimental design is an experimental research method widely used in social science. It is characterised by non-random group assignment or not including a pre-selection process due to the difficulties that random group assignment may pose. Nevertheless, these groups may be highly useful if the aim is to generate results for general trends, as is our case.

For this purpose, a questionnaire was administered to students belonging to the Faculty of Business Sciences and Tourism at the University of Vigo (UV, Spain). Of the 309 answers obtained, 303 were deemed to be valid. Though a random sampling was not used, we consider that the population size is big enough to be considered representative.

All the students who were in the classrooms on the dates when the surveys were administered between 1 December, 2016 and 7 March, 2017 formed the sample. The 20-minute test was carried out by students in the classroom supervised by the researchers. The students, 127 males and 176 females, of which 88 were enrolled on TM degree and 215 on BAM degree. The average age of the students was 21 , while $7.3 \%$ of the student sample was made up of foreigners.

The questionnaire was composed of two parts; the first consisted of questions on SDFs, while the second part was made up of a set of questions, aimed at measuring creativity in two different ways, one of them measures CP (RIBS) and the other DT (originality, fluency and flexibility).

The distribution of CP (RIBS) was normal ( $p>0.05$ ), while the measures of DT (originality, fluency and flexibility) were not $(\mathrm{p}=0.0001)$. Therefore, for the RIBS we shall use the Student's t-test for dichotomous variables, and the Analysis of variance for polytomous variables. We shall use the Mann-Whitney U test and the Kruskal-Wallis one-way analysis of variance for the measures of DT (originality, fluency and flexibility) in order to establish the relationships between the dichotomous and polytomous variables, respectively. The Pearson correlation coefficient will be used in the first case for the scale variables, and the Spearman-Brown prediction formula in the second.

A significance level of 0.05 was assumed in all the contrasts carried out. The data analysis was performed via the statistical package SPSS (version 22). 


\subsection{Measures}

\subsubsection{Sociodemographic factors}

A series of variables related to certain SDFs displayed by those surveyed were included in the proposed questionnaire:

Gender: this was measured by asking the participants to indicate whether they were male or female. Female was coded as 1 and male as 2 .

Degree and academic year: the study was carried out in the Faculty of Business Sciences and Tourism in the UV, where students can choose between two Management degrees, TM and BAM. The reason behind contrasting two Management degrees is that the competences that students should necessarily acquire on each of these courses are different, and are specified in the verification statement of each degree. Thus, creativity is included as a basic crosscurricular competence to be developed in TM, but not in BAM. TM was coded as 1 and BAM as 2. Additionally, students were asked to include the academic year they were in, bearing in mind that degrees last four years in Spain.

Employment status: students were asked whether they were studying or juggling studies with some type of paid work. Studying and working was coded as 1, while studying alone was coded as 2 .

Entrepreneurial family: students were asked whether their parents had (had set up) their own business (coded as 1), or if they were employed (coded as 2).

Living at home or away from home: participants were asked to indicate if they were living away from home during their time at university. Living away from home (either flat-sharing with other students, living alone in a flat or in halls of residence) was coded as 1 and living at home as 2 .

\subsubsection{Creativity}

As mentioned earlier, the literature offers different points of view on the type of instruments for measuring creativity, with the DT test in all its variations being the most commonly used. Nevertheless, given that many authors consider these tests to be insufficient when measuring a construct as complex as creativity, two measures have been used; on the one hand, the RIBS which measures CP, and on the other, a construct with three of the four components that measure DT (originality, fluency and flexibility).

CP (RIBS) was evaluated with the "Everyday" creativity scale of the RIBS (Runco et al., 2001). The RIBS measures the frequency with which those surveyed generate new ideas in their everyday lives. The RIBS proved to be reliable in various earlier studies, as well as having good construct validity, discriminant validity and concurrent validity (Runco et al., 2001, 2014). The RIBS Everyday Creativity Scale applied is based on the "RIBS: short form" ("RIBS-sf"), which shows a high correlation with the original RIBS. Given that the RIBS-sf is easier to administer and has the same validity as the original RIBS, it would seem to be the appropriate choice (Runco et al., 2014). The questionnaire administered to the participants in order to measure their CP is made up of 19 items, the answers to which adhere to a 5-point Likert scale: (1) never, (2) annually, (3) monthly, (4) weekly, (5) daily.

With regards to the measures of DT (based on Beketayev \& Runco, 2016; Runco, 1986; Wallach \& Kogan, 1965), a three-part structure with 9 questions was used, asking the partici- 
pants to do the following: (i) give alternative titles for a selection of films (Titanic (director James Cameron, 1997), Romeo \& Juliet (director Carlo Carlei, 2013), Harry Potter (directors Chris Columbus, Alfonso Cuarón, Mike Newell, David Yates, 2001-2011)); (ii) list as many possible applications for a series of services and products they could think of (rubbish bin, car steering wheel, computer mouse); and (iii) interpret the meaning of three figures. Scoring was based on the following elements:

Originality: The number of unique answers with respect to the other answers in the sample. Fluency: The total number of answers.

Flexibility: The number of different categories used.

Most of the DT tasks analysed with this instrument have been administered in English. In order to check reliability, the answers have therefore been translated to English, while originality and fluency have been rated independently in both languages, Spanish and English.

In order to confirm the reliability of the measure scale, Cronbach's alpha coefficient has been calculated, the results of which are presented in the Table 1 below.

Table 1. Cronbach's alpha coefficient (source: created by authors)

\begin{tabular}{|l|c|}
\hline \multicolumn{1}{|c|}{ Variables } & alpha \\
\hline Originality & 0.8673 \\
\hline Fluency & 0.8762 \\
\hline Flexibility & Not available \\
\hline RIBS-sf & 0.7469 \\
\hline
\end{tabular}

Originality and fluency gave a coefficient greater than 0.86 , while CP (RIBS-sf) was over 0.74; this implies high reliability in the first two cases and moderate reliability in the third (J. A. Gliem \& R. R. Gliem, 2003; Sijtsma, 2009). We have been unable to determine reliability for the flexibility score since it is based on a semantic analysis based on translations in English (Beketayev \& Runco, 2016).

The Kolmogorov-Smirnov test was used to determine the goodness of fit and hence, check the degree of compatibility between the sample distribution and its specific theoretical distribution. Its objective is to test if the observations could be reasonably derived from the described distribution (Table 2).

Table 2. Kolmogorov-Smirnov test for one sample (source: created by authors)

\begin{tabular}{|l|l|c|c|c|c|}
\hline \multicolumn{2}{|c|}{$\mathrm{N}=303$} & RIBS-sf & Originality & Fluency & Flexibility \\
\hline \multirow{2}{*}{ Normal parameters } & Mean & 60.77 & 13.56 & 19.60 & 5.89 \\
\cline { 2 - 6 } & Standard deviations & 9.492 & 9.539 & 13.264 & 5.439 \\
\hline \multirow{2}{*}{$\begin{array}{l}\text { Maximum external } \\
\text { differences }\end{array}$} & Absolute & .049 & .123 & .086 & .163 \\
\cline { 2 - 6 } & Positive & .045 & .123 & .086 & .163 \\
\cline { 2 - 6 } & Negative & -.049 & -.078 & -.070 & -.139 \\
\hline \multicolumn{2}{|l|}{ Statistical test } & .049 & .123 & .086 & .163 \\
\hline \multicolumn{2}{|l|}{ Significance (bilateral) } & .074 & .000 & .000 & .000 \\
\hline
\end{tabular}


Based on these data, parametric measures for RIBS-sf and nonparametric measures for DT tasks were used.

\section{Results: hypotheses testing}

The measures of DT (originality, fluency and flexibility) obtained very low scores. In contrast, CP (RIBS-sf) has a relatively high mean as it is close to the maximum score (Tables 3, 5).

Skewness (originality $=1.441$; fluency $=1.040$; flexibility $=1.505$ ) and kurtosis (originality $=3.754$; fluency $=1.688$; flexibility $=2.328$ ) are positive in the measures of DT. The distribution therefore has a skewed tail towards positive values, that is, the values are closer together at levels below the arithmetic mean. In addition, the kurtosis is leptokurtic; as it is positive, there is a greater concentration of data around the mean. Regarding CP (RIBS-sf), skewness $(-.051)$ and kurtosis $(-.451)$ are negative, thus we can interpret it inversely to the DT variable.

An attempt has been made to determine whether there is an association between the measures of DT and CP (RIBS-sf) and the different independent variables previously described. To avoid an excessive number of tables, we have included only those in which significant differences were found (Tables 3, 5, 6).

The first hypothesis of this study, regarding the existence of differences in creativity according to gender, is rejected for CP (RIBS-sf) $(\mathrm{t}=.801 ; \mathrm{p}=.424)$. But, as it can be observed in Table 3, it is accepted for the three constructs of DT, given that the male students obtained a higher mean.

Hypothesis 2, that states that there are significant differences in creativity depending on the degree studies (BAM or TM), is rejected for the measures of CP (RIBS-sf) as no significant differences were found regarding the degree studied $(\mathrm{t}=-1.116 ; \mathrm{p}=.265)$. It is, however, accepted for the constructs of originality and fluency, with Business students obtaining the highest mean (Table 3).

The effect size (ES), specifically Cohen's $d(d=$ standardised mean difference) was also calculated. The interpretation of this index proposed by said author is as follows: an ES of 0.2 to 0.3 would be considered small; around 0.5 would be considered a medium ES, and 0.8 or higher can be taken to be a large ES (bearing in mind that $\mathrm{d}$ can be greater than 1 ). The ES in this study is small for the variables related with DT and degree, while they have a medium ES when analysed with the gender variable.

Regarding Hypothesis 3, that refers to the existence of differences in creativity depending on the academic year, it is rejected for both measures of creativity, as no differences were found relating to the academic year for either CP (RIBS-sf) $(\mathrm{F}=2.247 ; \mathrm{p}=.083)$ or for the measures of DT analysed (originality: Kruskal-Wallis $\chi^{2}=.982 ; \mathrm{p}=.806$; fluency: KruskalWallis $\chi^{2}=1.510 ; \mathrm{p}=.680$; flexibility: Kruskal-Wallis $\chi^{2}=.737$ and $\mathrm{p}=.865$ ).

Although there are no statistically significant differences between the groups, with students in the first year of both degrees having a similar mean for CP (RIBS-sf), we would like to point out that the mean decreases in both groups the later the degree year studied by the students. With respect to the variables related to DT, students in their first year of TM always have a higher mean than that of BAM students, however, the means for the three creativity 
Table 3. Frequencies for the constructs of divergent thinking based on gender, degree and the results of the Mann-Whitney U test (source: created by authors)

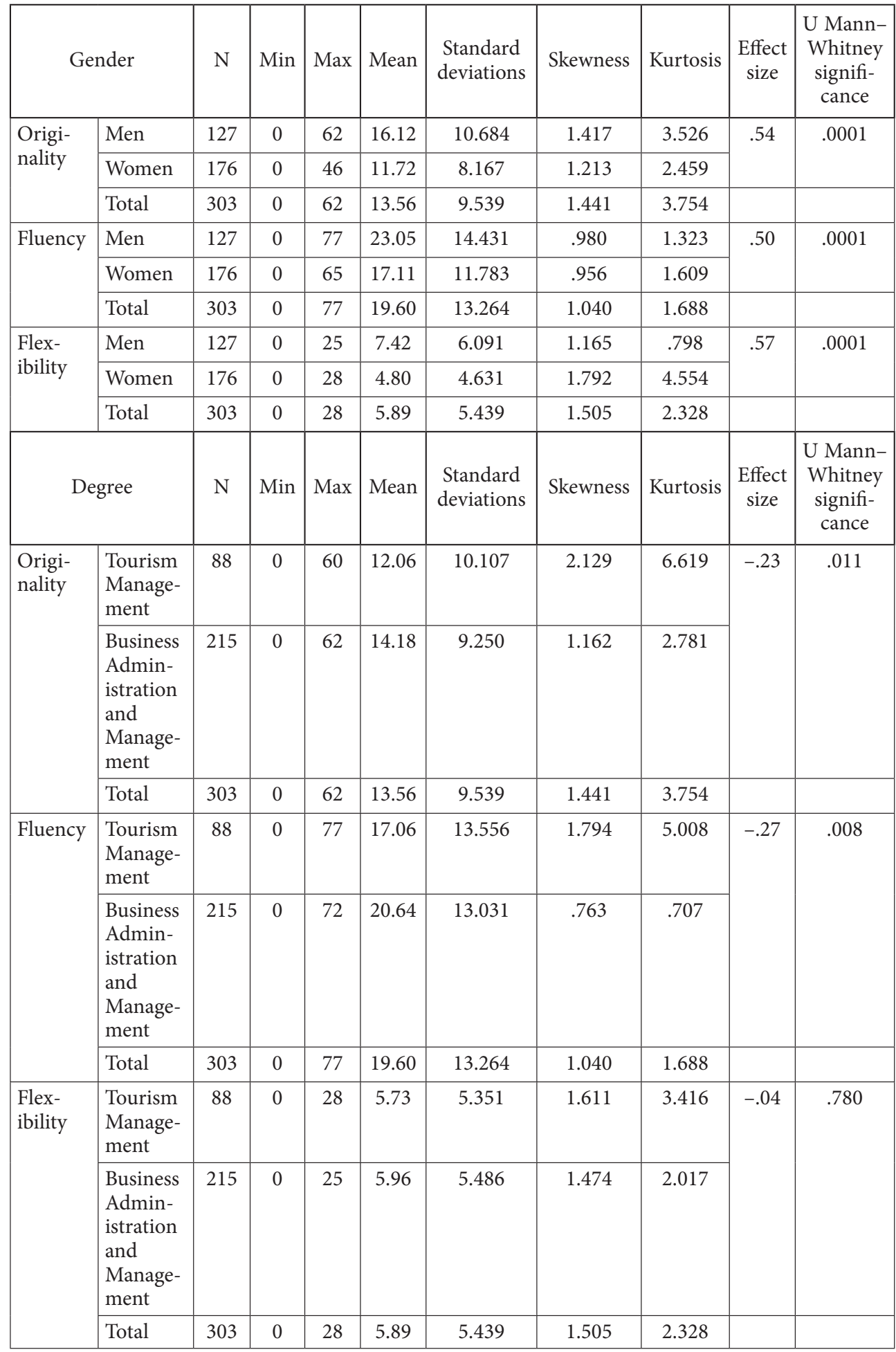


constructs diminishes the further along their degree the students find themselves. The exact opposite occurs with the BAM students, whereby the means for the three constructs increase over the degree years. We believe these results to be relevant to demonstrating that creativity is not promoted within the faculties (Table 4).

Table 4. Mean for each degree according to academic year (source: created by authors)

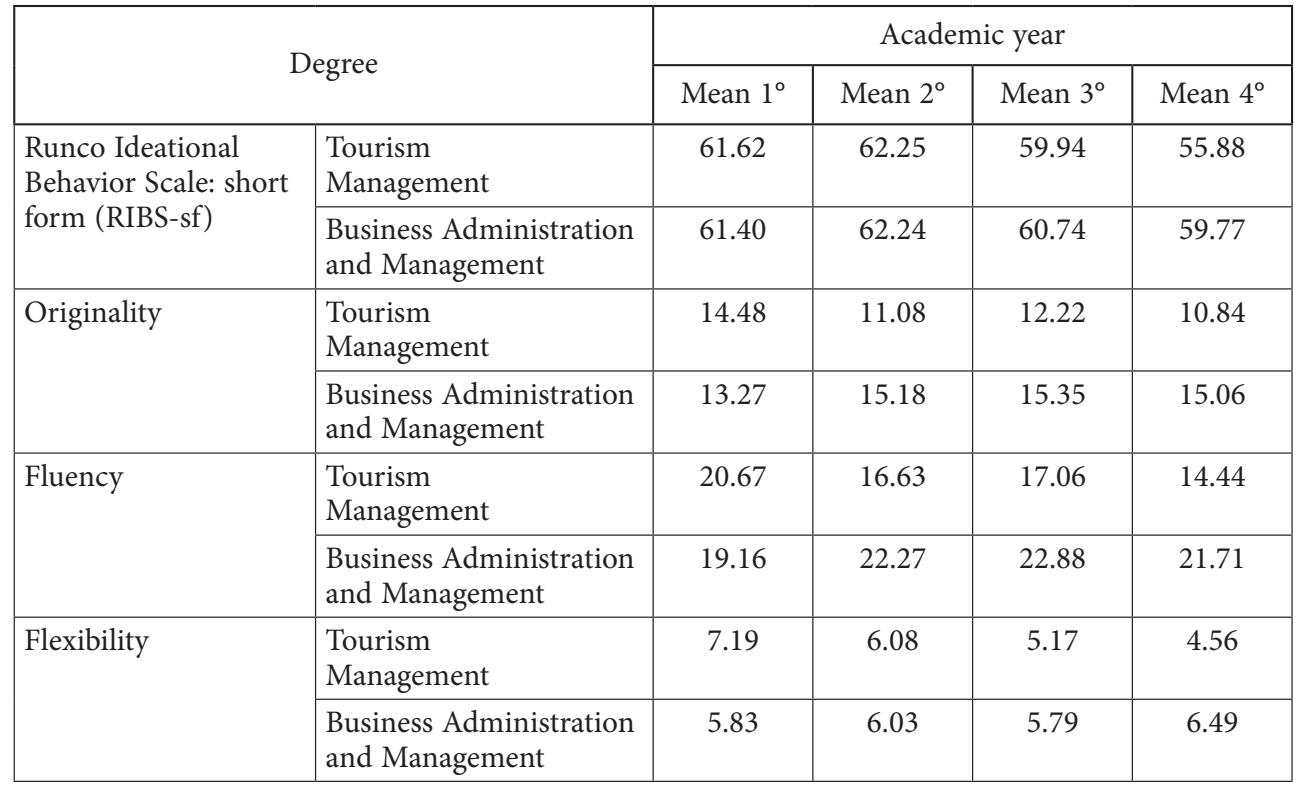

Hypothesis 4, that refers to the existence of differences in creativity based on the employment status of the student, significant differences were only observed in the case of CP (RIBS-sf), with those students who study and work at the same time obtaining the highest mean. The hypothesis for CP (RIBS-sf) is therefore accepted (Table 5), but rejected for the measures of DT (originality: $\mathrm{U}=-.129 ; \mathrm{p}=.897$; fluency: $\mathrm{U}=-.164 ; \mathrm{p}=.869$; flexibility: $\mathrm{U}=$ $-593 ; \mathrm{p}=.553$ ). The ES for the related variables RIBS-sf and employment status is small.

With respect to Hypothesis 5, which poses that there are differences in creativity based on the students from an entrepreneurial family, no significant differences have been observed in terms of whether or not students' parents were business owners. Thus Hypothesis 5 is rejected for both creativity measures (RIBS-sf: $\mathrm{t}=1.159 ; \mathrm{p}=.247$; originality: $\mathrm{U}=-1.279 ; \mathrm{p}=.201$; fluency: $\mathrm{U}=-1.457 ; \mathrm{p}=.145$; flexibility: $\mathrm{U}=-2.42 ; \mathrm{p}=.809)$.

Hypothesis 6, that refers to the existence of differences in creativity depending on the students' residence (living at home or away from home), is rejected both for RIBS-sf ( $\mathrm{t}=$ $1.560 ; \mathrm{p}=.120$ ) and DT except for the construct of flexibility, where the variable of living at home or away from home is significant. Those students who lived at home obtained the highest mean. The ES for the related variables DT and living at/away home is small (Table 6). 
Table 5. Frequencies for creative potential (Runco Ideational Behavior Scale: short form) based on employment status and the results of Student's t-test (source: created by authors)

\begin{tabular}{|c|c|c|c|c|c|c|c|c|c|c|}
\hline $\begin{array}{c}\text { Employ- } \\
\text { ment } \\
\text { status }\end{array}$ & & $\mathrm{N}$ & Min & Max & Mean & $\begin{array}{l}\text { Standard } \\
\text { deviations }\end{array}$ & $\begin{array}{c}\text { Skew- } \\
\text { ness }\end{array}$ & $\begin{array}{c}\text { Kurto- } \\
\text { sis }\end{array}$ & $\begin{array}{c}\text { Effect } \\
\text { size }\end{array}$ & $\begin{array}{l}\text { U Mann- } \\
\text { Whitney } \\
\text { signifi- } \\
\text { cance }\end{array}$ \\
\hline \multirow{3}{*}{$\begin{array}{l}\text { Runco Ide- } \\
\text { ational Be- } \\
\text { havior Scale: } \\
\text { short form } \\
\text { (RIBS-sf) }\end{array}$} & $\begin{array}{l}\text { Studying } \\
\text { and } \\
\text { Working }\end{array}$ & 50 & 44 & 78 & 63.22 & 7.544 & -.374 & -.220 & \multirow[t]{2}{*}{.30} & \multirow[t]{2}{*}{.019} \\
\hline & Studying & 253 & 35 & 86 & 60.28 & 9.771 & .036 & -.480 & & \\
\hline & Total & 303 & 35 & 86 & 60.77 & 9.492 & -.051 & -.451 & & \\
\hline
\end{tabular}

Table 6. Frequencies for the constructs of divergent thinking based on living at home or away from home and the results of the Mann-Whitney $U$ test (source: created by authors)

\begin{tabular}{|c|c|c|c|c|c|c|c|c|c|c|}
\hline $\begin{array}{r}\text { Living } \\
\text { from }\end{array}$ & $\begin{array}{l}\text { at/away } \\
\text { home }\end{array}$ & $\mathrm{N}$ & Min & Max & Mean & $\begin{array}{c}\text { Standard } \\
\text { deviations }\end{array}$ & $\begin{array}{c}\text { Skew- } \\
\text { ness }\end{array}$ & $\begin{array}{l}\text { Kurto- } \\
\text { sis }\end{array}$ & $\begin{array}{c}\text { Effect } \\
\text { size }\end{array}$ & $\begin{array}{c}\text { U } \\
\text { Mann- } \\
\text { Whitney }\end{array}$ \\
\hline Originality & At home & 154 & 0 & 62 & 14.42 & 9.988 & 1.326 & 3.189 & .19 & .076 \\
\hline & $\begin{array}{l}\text { Away from } \\
\text { home }\end{array}$ & 149 & 0 & 60 & 12.68 & 9.001 & 1.581 & 4.733 & & \\
\hline & Total & 303 & 0 & 62 & 13.56 & 9.539 & 1.441 & 3.754 & & \\
\hline Fluency & At home & 154 & 0 & 72 & 20.78 & 13.880 & .874 & .876 & .19 & .136 \\
\hline & $\begin{array}{l}\text { Away from } \\
\text { home }\end{array}$ & 149 & 0 & 77 & 18.38 & 12.526 & 1.240 & 3.045 & & \\
\hline & Total & 303 & 0 & 77 & 19.60 & 13.264 & 1.040 & 1.688 & & \\
\hline Flexibility & At home & 154 & 0 & 25 & 6.59 & 5.596 & 1.436 & 1.956 & .27 & .004 \\
\hline & $\begin{array}{l}\text { Away from } \\
\text { home }\end{array}$ & 149 & 0 & 28 & 5.17 & 5.193 & 1.626 & 3.016 & & \\
\hline & Total & 303 & 0 & 28 & 5.89 & 5.439 & 1.505 & 2.328 & & \\
\hline
\end{tabular}

\section{Conclusions and implications}

This study has analysed the level of creativity among university students and the way in which certain SDFs have an effect on their creativity. We can observe that students' CP (RIBS-sf) is relatively high, while the measures for DT obtained very low scores. This result highlights the need to foster the development of this ability among the student population. Thus, this competence should be promoted by the universities and considered an essential tool for successful integration into the current competitive work market, specifically in the business world.

The problem resides in the fact that currently there is no organised, planned and conscious creativity training in place within universities. We can normally find isolated, improvised activities aimed at encouraging this competence thanks to the personal initiative of the teaching staff. Thus, there is a growing interest among the staff to channel their teaching 
practice towards the development of creativity. Specific programmes to improve this competence would therefore be needed, which would entail redesigning existing teaching curriculums with the aim of promoting and attempting to evaluate the creativity within these programmes. Nevertheless, in order to meet this goal, the multiple variables of the targeted field need to be studied; the current way of building knowledge, the staff's teaching practices, the type of relationship the students have with staff, among other factors (Elisondo, Donolo, \& Rinaudo, 2009). The aim of the teaching staff should be to encourage students to develop their creativity acquisition along the lines of searching for and implementing the most creative solutions to the diverse range of problems that they should gradually be presented with, be they related to finance, production, customer services, the development of new products and services, strategy design, etc.

Offering specific training on creativity can have very positive general effects on students. As Todd Dewett and Melissa L. Gruys (2007) highlights both the level of creativity and students' self-perceptions of creativity improved as a result of their training (Master of Business Administration on creativity). This additional training and the subsequent increase in creativity could also help students to improve their academic achievement (Gajda, Karwowski, \& Beghetto, 2017).

With respect to the SDFs analysed, it is worth mentioning that the results highlight the fact that there are no significant differences in the students' CP (RIBS-sf) according to gender, whereas differences were identified in the three constructs of DT analysed, the greatest found with males. These results concur with those obtained in previous studies (Abra \& Valentine-French, 1991; Chadha, 1985), although various authors point out they should be treated cautiously due to the limited sample size (Rodríguez-Cano \& Mendoza-Fuentes, 2011), the academic context and the curriculum variables analysed in the studies (Limiñana Gras, Bordoy, Juste Ballesta, \& Corbalán Berna, 2010). While the previous research is not clear on the reasons behind the existence of differences in creativity between males and females, some authors suggest biological and genetic conditioning, or pressures of a social or cultural nature that favour creativity and performance among males while hindering creativity among females (Monreal, 2001).

No differences were observed based on the student's academic year either; nevertheless, while the differences were not significant, it has been observed that creativity measures generally decrease throughout the degree course. John S. Dacey and Kathleen H. Lennon (1998) state that the general decrease in creativity spanning one's education could be attributed to the growing complexity of problems and problem solving for people with higher studies. The problems posed in different subjects in later academic years are possibly more complicated and therefore the search for solutions may take up a considerable amount time and effort on the part of the students; this could lead them to dedicate less time to delving deep into their creative assets. Strict subject planning, the fulfilment of teaching curriculums, the type of evaluation used that demands evidence in case of complaints; all this leaves teaching staff with very little freedom or time to consider new scenarios beyond the established script that could encourage creative thinking.

Regarding the type of degree, significant differences were observed in the measures of DT which were higher for BM students than for TM students for the constructs of fluency 
and originality, while none were observed for flexibility. These results are surprising, given that creativity is included in the programme for TM as a competence to be developed, while it is not in the BAM degree. Nevertheless, the Business students are the ones who are more creative. This result reveals the fact that there is no coherence between the stated competences in the degree programmes and those that are actually developed during the teachinglearning processes in each subject. This points to the need for a rigorous evaluation of the degree programmes in our country in order to ensure that the competences included in the programmes are really developed in class. Additionally, previous studies showed that performance measures in DT tasks could be difference based on the degree studied (Cheung et al., 2003).

The reasons underlying the growing lack of creativity among the student body may be due to the rigidity of our education model, which is highly repetitive and offers few alternatives in knowledge building.

As far as the students' employment status is concerned, it would seem that CP (RIBS-sf) is greater among those students who combine studying and working; additionally, no significant differences were identified for DT measures. This may be a consequence of the fact that those students who juggle working and studying develop greater skills and abilities, have a different outlook on things, a greater ability to resolve problems or propose different solutions, which is in line with the results obtained in previous studies such as those by Curtis and Williams (2002) or Watts and Pickering (2000).

With respect to previous experiences of family entrepreneurship, no significant differences were observed in the creativity measures based on whether or not the students' parents were business owners. This could be an interesting result in light of encouraging those students with entrepreneurial ambitions, as it would seem that those students with entrepreneurial parents do not display a higher level of creative ideas, as previously pointed out in the study by María-del-Mar Camacho-Miñano and Cristina del Campo (2017).

Lastly, the only significant differences observed when we compare if the students live at home or away from home were in the case of flexibility. Results show that the students residing at their family home scored higher than those who did not. This indicates that students living at home show a greater variety and heterogeneity in the ideas they produce, broaching problems from different angles. The results are surprising, given the belief that students leaving the family context would have to develop their creative abilities to a greater extent when making decisions for themselves, looking for solutions for conflicts and problems thrown up by their new surroundings, all without any direct support from their parents.

Based on these results, we suggest various courses of action to promote tasks, activities and methodologies that boost students' creative development and innovation:

- Given the lower level of creativity among females, this could be encouraged through the design of specific courses or ensuring that the work groups for the practical part of their studies are coeducational.

- Redesigning the subjects with more creative activities in those degrees with lower levels of creativity, valuing students' capacity for innovation and creative thinking.

- Enlightening students on the advantages of working on their own through the promotion of entrepreneurialism.

- Facilitating the relationship between students and the business world through 
conferences, workshops, courses, debate committees with business people and visits to companies.

- Programming activities within university centres that include simulating the creation and management of companies; business simulators could be used to this effect.

- Giving the students the opportunity to resolve problems and design original projects that could be implemented in their future business activity.

- Fostering internships and work placement activities for all the students during their academic years.

Regarding the implications of this study, while the data obtained could be considered of interest to both student bodies and businesses, we believe that this research would have the greatest implications in the university context and specifically for teaching staff, with the aim of improving and fostering creative skills and designing actions and strategies that could increase creativity among the university student body.

\section{Limitations and future research}

In order to consolidate these results, it would be important to carry out comparative studies with other degrees and replicate the study in other European countries; in this way the possible differences in CP based on the various sociocultural and academic characteristics could be verified.

Likewise, another course of action to aid consolidation of these results and decisionmaking at an international level would be the analysis of other types of variables related to entrepreneurial intentions and the different family characteristics that may impact on individuals' creativity.

\section{References}

Abra, J. C., \& Valentine-French, S. (1991). Gender differences in creative achievement: a survey of explanations. Genetic, Social and General Psychology Monographs, 117(3), 233-284.

Ahmetoglu, G., Harding, X., Akhtar, R., \& Chamorro-Premuzic, T. (2015). Predictors of creative achievement: assessing the impact of entrepreneurial potential, perfectionism, and employee engagement. Creativity Research Journal, 27(2), 198-205. https://doi.org/10.1080/10400419.2015.1030293

Amabile, T. M. (1983). The social psychology of creativity: a componential conceptualization. Journal of Personality and Social Psychology, 45(2), 357-376. https://doi.org/10.1037/0022-3514.45.2.357

Association to Advance Collegiate Schools of Business. (2010). Business schools on an innovation mission. Report of the AACSB International: task force on business schools and innovation. Retrieved from https://www.aacsb.edu/ /media/AACSB/Publications/research-reports/business-schools-onan-innovation-mission.ashx

Baer, J., \& Kaufman, J. C. (2008). Gender differences in creativity. Journal of Creativity Behavior, 42(2), 75-105. https://doi.org/10.1002/j.2162-6057.2008.tb01289.x

Bagheri, A., \& Lope Pihie, Z. A. (2010). Role of family and entrepreneurial leadership development of university students. World Applied Sciences Journal, 11(4), 434-442.

Beketayev, K., \& Runco, M. A. (2016). Scoring divergent thinking tests by computer with a semanticsbased algorithm. Europe's Journal of Psychology, 12(2), 210-220.

https://doi.org/10.5964/ejop.v12i2.1127 
Biraglia, A., \& Kadile, V. (2017). The role of entrepreneurial passion and creativity in developing entrepreneurial intentions: insights from American homebrewers. Journal of Small Business Management, 55(1), 170-188. https://doi.org/10.1111/jsbm.12242

Broadbridge, A., \& Swanson, V. (2005). Earning and learning: how term-time employment impacts on students' adjustment to university life. Journal of Education and Work, 18(2), 235-249. https://doi.org/10.1080/13639080500086008

Burkšaitienè, N. (2018). How can university learning environment contribute to students' creativity? Lithuanian students' perspective. Creativity Studies, 11(1), 162-171. https://doi.org/10.3846/cs.2018.271

Camacho-Miñano, M.-del-M., \& Campo, del C. (2017). The role of creativity in entrepreneurship: an empirical study on business undergraduates. Education + Training, 59(7/8), 672-688. https://doi.org/10.1108/ET-08-2016-0132

Chadha, N. K. (1985). Creativity and cognitive style. Psycho-Lingua, 15(2), 81-88.

Chaiña Sucasaca, G. (2016). Influencia de las características sociodemográficas y los medios de enseñanza en la creatividad de los estudiantes de Enfermería de la UNJBG, Tacna 2015 (Tesis). Universidad Nacional Jorge Basadre Grohmann - Tacna, Facultad de Ciencias de la Salud, Escuela Académico Profesional de Enfermería. Tacna, Perú. Retrieved from http://repositorio.unjbg.edu.pe/bitstream/handle/UNJBG/2196/781_2016_chaina_sucasaca_g_facs_enfermeria.pdf?sequence=1\&isAllowed=y

Chen, Ch. C., Gene Greene, P., \& Crick, A. (1998). Does entrepreneurial self-efficacy distinguish entrepreneurs from managers? Journal of Business Venturing, 13(4), 295-316. https://doi.org/10.1016/S0883-9026(97)00029-3

Cheung, P. Ch., \& Lau, S. (2010). Gender differences in the creativity of Hong Kong school children: comparison by using the new electronic Wallach-Kogan creativity tests. Creativity Research Journal, 22(2), 194-199. https://doi.org/10.1080/10400419.2010.481522

Cheung, Ch.-K., Rudowicz, E., Yue, X., \& Kwan, A. S. F. (2003). Creativity of university students: what is the impact of field and year of study? Journal of Creative Behavior, 37(1), 42-63. https://doi.org/10.1002/j.2162-6057.2003.tb00825.x

Corbalán Berná, F. J., Martínez Zaragoza, F., Donolo, D. S., Alonso Monreal, C., Tejerina Arreal, M., \& Limiñana Gras, R. M. (2003). CREA. Inteligencia Creativa: Una medida Cognitiva de la Creatividad. Madrid: TEA Ediciones.

Couger, J. D. (1994). Creative problem solving and opportunity finding. Hinsdale, IL: Boyd \& Fraser Publishing Co.

Couger, J. D. (1996). Creativity \& innovation in information systems organizations. Danvers, MA: Boyd \& Fraser. https://doi.org/10.1109/HICSS.1996.495304

Crant, J. M. (1996). The proactive personality scale as a predictor of entrepreneurial intentions. Journal of Small Business Management, 34(3), 42-49.

Curtis, S., \& Williams, J. (2002). The reluctant workforce: undergraduates' part-time employment. Education + Training, 44(1), 5-10. https://doi.org/10.1108/00400910210416192

Dacey, J. S., \& Lennon, K. H. (1998). Understanding creativity: the interplay of biological, psychological, and social factors. San Francisco, CA: Jossey-Bass, Inc.

D’Amico, R. (1984). Does employment during high school impair academic progress? Sociology of Education, 57(3), 152-164. https://doi.org/10.2307/2112599

Dewett, T., \& Gruys, M. L. (2007). Advancing the case for creativity through graduate business education. Thinking Skills and Creativity, 2(2), 85-95. https://doi.org/10.1016/j.tsc.2007.04.001

Durón, L., \& Oropeza, R. (1999). Actividades de estudio: análisis predictivo a partir de la interacción familiar y escolar de estudiantes de nivel superior. Documento de trabajo. Facultad de Psicología, Universidad Nacional Autónoma de México. México: UNAM. 
Eggers, F., Lovelace, K. J., \& Kraft, F. (2017). Fostering creativity through critical thinking: the case of business start-up simulations. Creativity and Innovation Management, 26(3), 266-276. https://doi.org/10.1111/caim.12225

Elisondo, R. C., Donolo, D. S., \& Rinaudo, M. C. (2009). Ocasiones para la creatividad en contextos de educación superior. Revista de Docencia Universitaria, 7(4). Retrieved from https://polipapers.upv. es/index.php/REDU/article/view/6233/6283

Epstein, R., Kaminaka, K., Phan, V., \& Uda, R. (2013). How is creativity best managed? Some empirical and theoretical guidelines. Creativity and Innovation Management, 22(4), 359-374. https://doi.org/10.1111/caim.12042

Esquivias Serrano, M. T. (2004). Creatividad: definiciones, antecedentes y aportaciones. Revista Digital Universitaria, 5(1), 1-17.

Fekula, M. J. (2011). Managerial creativity, critical thinking, and emotional intelligence: convergence in course design. Business Education Innovation Journal, 30(2), 92-101.

Fitó-Bertran, À., Hernández-Lara, A. B., \& Serradell-López, E. (2014). Comparing student competences in a face-to-face and online business game. Computers in Human Behavior, 30, 452-459. https://doi.org/10.1016/j.chb.2013.06.023

Gajda, A., Karwowski, M., \& Beghetto, R. A. (2017). Creativity and academic achievement: a metaanalysis. Journal of Educational Psychology, 109(2), 269-299. https://doi.org/10.1037/edu0000133

Ghosh, K. (2014). Creativity in business schools: towards a need based developmental approach. Global Journal of Flexible Systems Management, 15(2), 169-178. https://doi.org/10.1007/s40171-013-0049-2

Gliem, J. A., \& Gliem, R. R. (2003, 8-10 October). Calculating, interpreting, and reporting Cronbach's Alpha reliability coefficient for likert-type scales. Proceedings of Midwest Research to Practice Conference in Adult, Continuing, and Community Education (pp. 82-88). Midwest Research to Practice Conference in Adult, Continuing, and Community Education 2003. Columbus, Ohio, United States.

Guilford, J. P. (1962). Factors that aid and hinder creativity. Teachers College Record, 63, 380-392.

Guilford, J. P. (1956). The structure of intellect. Psychological Bulletin, 53(4), 267-293. https://doi.org/10.1037/h0040755

Gundry, L. K., Ofstein, L. F., \& Kickul, J. R. (2014). Seeing around corners: how creativity skills in entrepreneurship education influence innovation in business. The International Journal of Management Education, 12(3), 529-538. https://doi.org/10.1016/j.ijme.2014.03.002

Hartley, J., \& Greggs, M. A. (1997). Divergent thinking in arts and science students: contrary imaginations at Keele revisited. Studies in Higher Education, 22(1), 93-97. https://doi.org/10.1080/03075079712331381161

Holmes, V. (2008). Working to live: why university students balance full-time study and employment. Education + Training, 50(4), 305-314. https://doi.org/10.1108/00400910810880542

Kachelmeier, S. J., Reichert, B. E., \& Williamson, M. G. (2008). Measuring and motivating quantity, creativity, or both. Journal of Accounting Research, 46(2), 341-373. https://doi.org/10.1111/j.1475-679X.2008.00277.x

Kaufman, J. C., Baer, J., Agars, M. D., \& Loomis, D. (2010). Creativity stereotypes and the consensual assessment technique. Creativity Research Journal, 22(2), 200-205. https://doi.org/10.1080/10400419.2010.481529

Kerr, Ch., \& Lloyd, C. (2008a, 9-12 September). Developing creativity and innovation in management education: an artful event for transformative learning. Proceedings of the Fourth Art of Management and Organisation Conference. The Fourth Art of Management and Organisation Conference 2008. Banff, Alberta, Canada. Retrieved from https://core.ac.uk/download/pdf/10898903.pdf

Kerr, Ch., \& Lloyd, C. (2008b). Pedagogical learnings for management education: developing creativity and innovation. Journal of Management and Organization, 14(5), 486-503.

https://doi.org/10.5172/jmo.837.14.5.486 
Limiñana Gras, R. M., Bordoy, M., Juste Ballesta, G., \& Corbalán Berna, J. (2010). Creativity, intelectual abilities and response styles: implications for academic performance in the secondary school. Anales de Psicología, 26(2), 212-219.

Lucas, R., \& Lammont, N. (1998). Combining work and study: an empirical study of full-time students in school, college and university. Journal of Education and Work, 11(1), 41-56. https://doi.org/10.1080/1363908980110103

Matud, M. P., Rodríguez, C., \& Grande, J. (2007). Gender differences in creative thinking. Personality and Individual Differences, 43(5), 1137-1147. https://doi.org/10.1016/j.paid.2007.03.006

McIntyre, F. S., Hite, R. E., \& Kay Rickard, M. (2003). Individual characteristics and creativity in the marketing classroom: exploratory insights. Journal of Marketing Education, 25(2), 143-149. https://doi.org/10.1177/0273475303254014

McMullan, W. E., \& Kenworthy, Th. P. (2015). Creativity and entrepreneurial performance: a general scientific theory. Series: exploring diversity in entrepreneurship. Cham: Springer International Publishing.

Monreal, C. (2001). Qué es la creatividad. Madrid: Editorial Biblioteca Nueva.

Pefanis Schlee, R., \& Harich, K. R. (2014). Teaching creativity to business students: how well are we doing? Journal of Education for Business, 89(3), 133-141. https://doi.org/10.1080/08832323.2013.781987

Penagos-Corzo, J. C., \& Aluni, R. (2000). Preguntas más frecuentes sobre creatividad. Creatividad e Innovación: Cursos, Técnicas, Información. Retrieved from http://inteligenciacreatividad.com/recursos/revista-psicologia/revista-psicologia-9/index.html

Phipps, S. T. A. (2012). Contributors to an enterprising gender: examining the influence of creativity on entrepreneurial intentions and the moderating role of political skill controlling for gender. Academy of Entrepreneurship Journal, 18(1), 77-90.

Rinaudo, M. C., \& Donolo, D. (1999). ¿Creatividad en educación? Retos actuales de la enseñanza universitaria. Contextos de Educación, 1(2), 202-219.

Rodríguez-Cano, R. A., \& Mendoza-Fuentes, E. M. (2011). El Pensamiento divergente en universitarios: diferencias entre alumnos de psicología y de Bellas Artes. International Journal of Developmental and Educational Psychology, 3(1), 299-305.

Rogers, C. R. (1959). Toward a theory of creativity. In H. H. Anderson (Ed.), Creativity and its cultivation (pp. 69-82). New York, NY: Harper \& Row.

Runco, M. A. (2006). Creativity is always personal and only sometimes social. In J. A. Schaler (Ed.), Howard Gardner under fire: the rebel psychologist faces his critics (pp. 169-182). Series: Under Fire. Vol. 2. Chicago, IL: Carus Publishing Company.

Runco, M. A. (2007). Creativity. Theories and themes: research, development, and practice. Burlington, MA: Elsevier Academic Press.

Runco, M. A. (1986). Flexibility and originality in children's divergent thinking. The Journal of Psychology, 120(4), 345-352. https://doi.org/10.1080/00223980.1986.9712632

Runco, M. A., \& Acar, S. (2012). Divergent thinking as an indicator of creative potential. Creativity Research Journal, 24(1), 66-75. https://doi.org/10.1080/10400419.2012.652929

Runco, M. A., Ebersole, P., \& Mraz, W. (1991). Creativity and self-actualization. Journal of Social Behavior \& Personality, 6(5), 161-167.

Runco, M. A., Plucker, J. A., \& Lim, W. (2001). Development and psychometric integrity of a measure of ideational behavior. Creativity Research Journal, 13(3-4), 393-400. https://doi.org/10.1207/S15326934CRJ1334_16

Runco, M. A., Walczyk, J. J., Acar, S., Cowger, E. L., Simundson, M., \& Tripp, S. (2014). The incremental validity of a short form of the ideational behavior scale and usefulness of distractor, contraindicative, and lie scales. Journal of Creative Behavior, 48(3), 185-197. https://doi.org/10.1002/jocb.47 
Sanz de Acedo Baquedano, M. T., \& Sanz de Acedo Lizarraga, M. L. (2012). A correlational and predictive study of creativity and personality of college students. The Spanish Journal of Psychology, 15(3), 1081-1088. https://doi.org/10.5209/rev_SJOP.2012.v15.n3.39398

Shalley, C. E., Zhou, J., \& Oldham, G. R. (2004). The effects of personal and contextual characteristics on creativity: where should we go from here? Journal of Management, 30(6), 933-958. https://doi.org/10.1016/j.jm.2004.06.007

Scherer, R. F., Adams, J. S., Carley, S. S., \& Wiebe, F. A. (1989). Role model performance effects on development of entrepreneurial career preference. Entrepreneurship: Theory and Practice, 13(3), 53-72. https://doi.org/10.1177/104225878901300306

Schmitt-Rodermund, E. (2004). Pathways to successful entrepreneurship: parenting, personality, early entrepreneurial competence, and interests. Journal of Vocational Behavior, 65(3), 498-518.

Schmidt-Wilk, J. (2011). Fostering management students' creativity. Journal of Management Education, 35(6), 775-778. https://doi.org/10.1177/1052562911427126

Sijtsma, K. (2009). On the use, the misuse and the very limited usefulness of Cronbach's Alpha. Psychometrika, 74(1), 107-120. https://doi.org/10.1007/s11336-008-9101-0

Simonton, D. K. (1988). Scientific genius: a psychology of science. Cambridge: Cambridge University Press.

Soler, M. I. (2003). Creatividad en el ámbito universitario: la experiencia de Chile. Creatividad y Sociedad, 3, 39-45.

Sorensen, L., \& Winn, S. (1993). Student loans: a case study. Higher Education Review, 25(3), 48-65.

Stoltzfus, G., Nibbelink, B. L., Vredenburg, D., \& Thyrum, E. (2011). Gender, gender role, and creativity. Social Behavior and Personality: An International Journal, 39(3), 425-432.

https://doi.org/10.2224/sbp.2011.39.3.425

Tarling, C., Jones, P., \& Murphy, L. (2016). Influence of early exposure to family business experience on developing entrepreneurs. Education + Training, 58(7/8), 733-750. https://doi.org/10.1108/ET-03-2016-0050

The European Parliament and the Council of the European Union. (2006). Recommendation of the European Parliament and of the Council of 18 December 2006 on Key Competences for Lifelong Learning. Official Journal of the European Union. Retrieved from https://eur-lex.europa.eu/LexUriServ/LexUriServ.do?uri=OJ:L:2006:394:0010:0018:en:PDF4

Torrance, E. P. (1998). Torrance tests of creative thinking: norms technical-manual figural (streamlined) forms A \& B. Bensenville, IL: Scholastic Testing Service.

Torrance, E. P. (1966). Torrance tests of creative thinking: norms technical-manual research edition. Verbal tests, forms A and B. Figural tests, Forms $A$ and B. Princeton: Personnel Press.

Wallach, M. A., \& Kogan, N. (1965). Modes of thinking in young children: a study of the creativityintelligence distinction. Oxford: Holt, Rinehart \& Winston.

Wang, S.-Ch., Peck, K. L., \& Chern, J.-Y. (2010). Difference in time influencing creativity performance between design and management majors. International Journal of Technology and Design Education, 20(1), 77-93. https://doi.org/10.1007/s10798-008-9059-3

Watts, C. (2002). The effects of term-time employment on academic performance. Education + Training, 44(2), 67-75. https://doi.org/10.1108/00400910210419964

Watts, C., \& Pickering, A. (2000). Pay as you learn: student employment and academic progress. Education + Training, 42(3), 129-135. https://doi.org/10.1108/00400910010372670

Webster, M. A., \& Walker, M. B. (1981). Divergent thinking in arts and science students: the effect of item content. British Journal of Psychology, 72(3), 331-338. https://doi.org/10.1111/j.2044-8295.1981.tb02192.x

Wilson, F., Kickul, J., \& Marlino, D. (2007). Gender, entrepreneurial self-efficacy, and entrepreneurial career intentions: implications for entrepreneurship education. Entrepreneurship: Theory and Practice, 31(3), 387-406. https://doi.org/10.1111/j.1540-6520.2007.00179.x 
Wynder, M. (2008). Motivating creativity through appropriate assessment: lessons for management accounting educators. e-Journal of Business Education \& Scholarship of Teaching, 2(2), 12-27.

Zampetakis, L. A. (2008). The role of creativity and proactivity on perceived entrepreneurial desirability. Thinking Skills and Creativity, 3(2), 154-162. https://doi.org/10.1016/j.tsc.2008.07.002

Zampetakis, L. A., Gotsi, M., Andriopoulos, C., \& Moustakis, V. (2011). Creativity and entrepreneurial intention in young people: empirical insights from business school students. The International Journal of Entrepreneurship and Innovation, 12(3), 189-199. https://doi.org/10.5367/ijei.2011.0037

Zampetakis, L. A., \& Moustakis, V. (2006). Linking creativity with entrepreneurial intentions: a structural approach. The International Entrepreneurship and Management Journal, 2(3), 413-428. https://doi.org/10.1007/s11365-006-0006-Z

Zhang, L.-F. (2010). Do age and gender make a difference in the relationship between intellectual styles and abilities? European Journal of Psychology of Education, 25(1), 87-103. https://doi.org/10.1007/s10212-009-0006-9

Zhou, J. (2007). Leading for creativity: an employee-manager dyadic approach. In T. Davila, M. J. Epstein, \& R. Shelton (Eds.), The creative enterprise: managing innovative organizations and people (pp. 17-36). Vol. 2: Culture. Series: Praeger Perspectives. Westport, London: Praeger.

\title{
VERSLO IR TURIZMO VADYBOS UNIVERSITETO STUDENTŲ KÜRYBIŠKUMAS: APIBRĖŽIANT SOCIODEMOGRAFINIUS VEIKSNIUS
}

\author{
Mercedes MAREQUE, Elena DE PRADA, Margarita PINO-JUSTE
}

\begin{abstract}
Santrauka
Vyrauja aiški sąsaja tarp kūrybiškumo lygių, antreprenerystès ir ịsidarbinimo galimybių, o tai reiškia, kad studentams, siekiantiems aukštojo išsilavinimo, reikia igyti kūrybinių igūdžių ir gebėjimų. Dèl šios priežasties šiame tyrime siekiama išanalizuoti kūrybiškumo lygius tarp universiteto studentų ir patikrinti, ar tam tikri sociodemografiniai veiksniai turi įtakos kūrybiškumui. Vertinant kūrybiškumą buvo taikomi du būdai: viena vertus, divergentinis mąstymas buvo matuojamas pasitelkiant tris užduotis, o originalumas, sklandumas ir lankstumas bei kūrybinis potencialas (idejizavimas - Runco idejizuojančio elgesio skalè) - pasinaudojant kitais metodais. 2016-2017 mokslo metais buvo apklausti 303 verslo ir turizmo vadybos specializacijos studentai. Rezultatai parodè, kad mūsų studentų kūrybinis potencialas (Runco idejjizuojančio elgesio skalè) yra gana aukštas, tuo tarpu divergentinio mąstymo galimybès (originalumas, sklandumas ir lankstumas) buvo kur kas prastesnès. Tris divergentinio mąstymo konstruktų skirtumus lemia lytimi grindžiami skirtumai - vyriškos lyties asmenys gavo aukštesnius įvertinimus; panaši situacija susikloste sklandumo ir originalumo konstruktų atvejais - išryškejjo priklausomybè nuo studijuojamos specializacijos: verslo specializacijos studentai pademonstravo aukštesnius vidutinius rezultatus. Be to, tie studentai, kurie gyvena savo šeimose, gavo aukštesnius įvertinimus lankstumo atžvilgiu nei tie, kurie gyvena atskirai nuo jų. Taipogi studentų kūrybinis potencialas (Runco idejjizuojančio elgesio skalè) yra kur kas didesnis tarp tų, kurie ir studijuoja, ir dirba. Šiais rezultatais pabrežiama būtinybė skatinti Ispanijos studentų kūrybiškumą.
\end{abstract}

Reikšminiai žodžiai: kūrybiškumas, kūrybinis potencialas, divergentinis mąstymas, sociodemografiniai veiksniai, verslo administravimo ir vadybos studentai, turizmo vadybos studentai. 